DOI : $10.14746 /$ rie.2021.15.26

\title{
Janusz Józef Węc, Germany's Position on the System Reform of the European Union in the 2002-2016, Wydawnictwo Peter Lang, Berlin 2018, ss. 288.
}

Pierwsze dwie dekady XXI w. w Unii Europejskiej były czasem intensywnych wydarzeń, które w ogromny sposób wpłynęły na obecną formułę i kompetencje tej organizacji. W tym okresie można symbolicznie wydzielić dwa następujące po sobie procesy. Pierwszy z nich charakteryzowały reformy ustrojowe w dużym stopniu zaplanowane. Obrady Konwentu w sprawie przyszłości w Europie w latach 2002-2003 doprowadziły do opracowania projektu traktatu konstytucyjnego, który następnie był przedmiotem obrad konferencji międzyrządowej w latach 2003-2004. Proces ten, mimo, że chwilowo wstrzymany przez odrzucenie projektu traktatu konstytucyjnego w referendach w Holandii i Francji, szybko był kontynuowany. W efekcie 13 grudnia 2007 r. państwa członkowskie przyjęły traktat lizboński, który wieńczył proces zmian ustrojowych zainicjowanych na początku wieku. Drugi z procesów, który w XXI w. wpłynął nie tylko na strukturę instytucjonalną UE, ale także podzielił politycznie państwa członkowskie, kształtowały kryzysy - zadłużeniowy w strefie euro (od 2010 r.) oraz kryzys migracyjny (od 2015 r.). Reformy ustrojowe były więc niejako wymuszone koniecznością szybkiej reakcji na owe nagłe wydarzenia.

O każdym z wyżej opisanych wydarzeń powstało wiele prac opisujących przyczyny i analizujących skutki polityczne, gospodarcze i społeczne. Niemniej wciąż brakuje opracowań naukowych, które zgłębiają temat na tyle szczegółowo, że uzyskane wyniki badań nie tylko poszerzają naszą wiedzę, ale mogą także służyć, jako eksperckie studium przydatne dla sfery politycznego praxis. Książka autorstwa Janusza Józefa Węca Germany's Position on the System Reform of the European Union in 2002-2016 zdecydowanie spełnia te warunki. Za taka oceną przemawia szereg faktów. Po pierwsze, publikacja oparta jest na solidnej i klarownej metodologii. Po drugie, autor zadbał o przejrzystość struktury i prowadzonej narracji. Po trzecie wreszcie, książka, mimo że opisuje wydarzenia z coraz bardziej odległej przeszłości, zawiera wciąż bardzo aktualne konkluzje, które powinny budzić zainteresowanie nie tylko badawczy, ale także praktyków.

Celem książki autorstwa Janusza Józefa Węca jest analiza stanowiska rządu niemieckiego wobec reformy traktatowej UE w latach 2002-2009, a także zmian w unijnym prawie pochodnym wywołanych kryzysem zadłużeniowym strefy euro oraz kryzysem migracyjnym Unii. Praca obejmuje więc okres piętnastu lat (lata 2002-2016). Jest to wystarczający czas, aby móc zaobserwować zmiany w procesach politycznych na arenie międzynarodowej. Wybór dotyczący zarówno cezury czasowej pracy, jak i jej zakresu przedmiotowego jest dobrze zaplanowany. Pozwala to autorowi w sposób przejrzysty dla czytelnika prześledzić ewolucję stanowiska jednego z państw-liderów Unii Europejskiej wobec przełomowych dla tej organizacji reform ustrojowych w XXI w.

Istotne z punktu widzenia poznawczego są postawione w książce hipotezy. Pierwsza stwierdza, że rząd niemiecki odegrał pierwszoplanową rolę w reformie traktatowej UE w latach 2002-2005 i 2005-2009, co skutkowało wzmocnieniem Unii, ale także bardzo korzystnym dla Niemiec nowym układem sił w mechanizmie podejmowania decyzji w Radzie Unii Europejskiej oraz Radzie Europejskiej. Druga hipoteza opiera się na stwierdzeniu, że rząd niemiecki wywarł nie tylko realny wpływ na kryzys zadłużeniowy strefy euro, ale także jej reformy przeprowadzone w latach 2012-2016, co doprowadziło do znaczącego wzmocnienia ekonomicznego i politycznego Niemiec w UE. Trzecia hipoteza zakłada, że błędne decyzje rządu 
federalnego $\mathrm{w}$ walce $\mathrm{z}$ kryzysem migracyjnym w UE doprowadziły do osłabienia pozycji tego kraju na arenie unijnej. Weryfikacja trzech wymienionych hipotez przeprowadzona na kartach książki pozwala na wypełnienie luki badawczej w polskiej politologii oraz studiach europejskich. Taka konceptualizacja problemu badawczego powinna także zwrócić uwagę praktyków, gdyż niesie ze sobą dużą wartość eksplanacyjną działań politycznych jednego najważniejszych graczy w Unii Europejskiej.

Bez wątpienia ogromną wartością pracy jest to, że autor opiera ją na bardzo bogatym materiale źródłowym. Janusz Józef Węc wykorzystuje liczne akty prawa pierwotnego i wtórnego Unii Europejskiej, dokumenty instytucji unijnych oraz innych organizacji międzynarodowych, a także dokumenty rządu niemieckiego, Bundestagu oraz niemieckich partii politycznych. Bazę źródłową uzupełniają liczne opracowania monograficzne oraz artykuły naukowe i ekspertyzy.

Janusz Józef Węc w swojej książce prowadzi wywód chronologicznie. Pierwszy rozdział przedstawia stanowisko, jakie Niemcy zajmowali wobec zmian ustrojowych Wspólnot Europejskich oraz Unii Europejskiej negocjowanych w czasie czterech konferencji międzyrządowych w ostatniej dekadzie XX w. Tym samym rozdział ten ma charakter kontekstowy. Po pierwsze, wprowadza czytelnika w tematykę reform ustrojowych w UE, wskazując, jakie rozwiązania, czy to w ramach Wspólnoty Europejskiej, czy to Unii Gospodarczej i Walutowej były przedmiotem szczególnego zainteresowania Niemiec. Po drugie, rozdział pierwszy jasno osadza narrację książki w paradygmacie międzyrządowym, który zakłada dominujący wpływ państw na proces integracji np. poprzez zabiegi dyplomatyczne w czasie konferencji międzyrządowych.

Rozdział drugi wprowadza czytelnika w dyskusje nad szczegółowymi rozwiązaniami instytucjonalnymi oraz materialnymi, które były przedmiotem obrad Konwentu w sprawie przyszłości Europy (lata 2002-2003), a następnie konferencji międzyrządowej rozpatrującej projekt traktatu konstytucyjnego (lata 2003-2004). Autor precyzyjnie przedstawia stanowiska i wpływ koalicji rządowej SPD i Sojuszu'90/Zielonych, a także partii opozycyjnych wobec takich kwestii jak system instytucjonalny, wzmocniona współpraca, legitymacja demokratyczna UE, czy reforma wspólnej polityki zagranicznej i bezpieczeństwa.

Rozdział trzeci zawiera analizę kluczowej roli prezydencji niemieckiej w wyjściu z kryzysu spowodowanego odrzuceniem traktatu konstytucyjnego w referendach w Holandii i Francji. Badanie stanowiska Niemiec wobec kwestii ustrojowych w UE nie może pomijać roli, jaką odgrywa orzecznictwo Federalnego Trybunału Konstytucyjnego. Dlatego za cenny wątek poruszony w rozdziale trzecim należy uznać opis orzeczenia FTK z 30 czerwca 2009 r., w którym niemiecki sąd konstytucyjny uznał traktat lizboński za zgodny Ustawą Zasadniczą RFN. Zdaniem FTK UE nie przekształca się w federację, a instytucje unijne nie mogą samodzielnie zmieniać podstaw traktatowych. FTK tym samym zastrzegł, że rola parlamentu niemieckiego w polityce europejskiej powinna zostać wzmocniona, a przekształcenie UE w strukturę federalną wymagać będzie zmiany konstytucji i bezpośredniej zgody narodu niemieckiego.

Szczególnie duże znaczenie dla weryfikacji hipotez postawionych w książce mają rozdziały czwarty i piąty dotyczące odpowiednio reformy Unii Gospodarczej i Walutowej oraz polityk migracyjnej, azylowej i kontroli granic. W rozdziale czwartym autor szczegółowo omawia stanowisko rządu Niemiec i głównych partii politycznych wobec propozycji ustanowienia Unii Bankowej, Unii Fiskalnej oraz Unii Gospodarczej, które miały ukonstytuować w pełni UGiW. Podejście do omawiania kryzysu migracyjnego i jego wpływu na UE zasługuje na szczególną uwagę. Janusz Józef Węc w rozdziale piątym nie skupia się tylko na wydarzeniach z 2015 r., które bezpośrednio wpłynęły na załamanie się zdolności państw członkowskich do przejmowania migrantów. Analizę przyczyn problemów, z którymi Unia boryka się do dziś autor rozpoczyna od pierwszych symptomów zwiększonego napływu migrantów, który można było zauważyć już w 2011 r., bezpośrednio po Arabskiej Wiośnie. W rozdziale piątym na szczególną uwagę 
czytelników zasługuje klarowne i precyzyjne wyjaśnienie zmian w trzech z sześciu głównych dla bezpieczeństwa wewnętrznego politykach unijnych.

Zarówno kwestia wzmacniania zarządzania finansowego i gospodarczego w UE, jak i budowa efektywnego mechanizmu radzenia sobie z presją migracyjną na zewnętrznych graniach UE są zagadnieniami, które wciąż rezonują w UE. Dotykają one kwestii fundamentalnych dla integracji europejskiej, takich jak federacyjny model UE, czy suwerenne kompetencji państw członkowskich do ochrony swoich obywateli. Ze względu na wysoką konkurencyjność gospodarki niemieckiej, największy udział finansowy tego kraju na rzecz stabilizacji gospodarek zadłużonych państw strefy euro, a także atrakcyjny rynek pracy to właśnie to państwo jest najbardziej zdeterminowane, aby skutecznie uregulować wadliwe rozwiązania UGiW oraz unijnego systemu azylowego. Przeprowadzona w książce analiza stanowisk rządu niemieckiego pozwala lepiej zrozumieć motywacje polityczne, którymi kieruje się to państwo w swojej polityce europejskiej.

Książka Janusza Józefa Węca w niezwykle skrupulatny, ale przy tym przejrzysty sposób przedstawia ewolucję stanowiska Niemiec wobec przekształceń ustrojowych w UE w ostatnich dwóch dekadach. Ten ambitny cel udało się autorowi w pełni zrealizować, zaś wnioski, które wpłyną z lektury są niezwykle interesujące. Traktat lizboński oraz rola, jaką Niemcy odegrały podczas kryzysu zadłużeniowego, wzmocnił pozycję tego kraju jako lidera UE. Kilka lat później, w wyniku błędnych decyzji rządu federalnego zwiększających destabilizację w zarządzaniu przepływami migrantów, pozycja ta uległa osłabieniu. Ze względu na polityczne znaczenie Niemiec dla procesu integracji europejskiej i konieczność rozwiązania szeregu problemów, jakie stoją przed UE, książka Janusza Józefa Węca ma nie tylko istotny wymiar naukowy, ale także powinna być lekturą praktyków i decydentów politycznych tworzących polską politykę europejską.

MICHAE DULAK

Uniwersytet Jagielloński w Krakowie ORCID: 0000-0002-7737-5236 